\title{
Corn Oil
}

National Cancer Institute

\section{Source}

National Cancer Institute. Corn Oil. NCI Thesaurus. Code C392.

An oil extracted from the germ of corn. Refined corn oil is about $59 \%$ polyunsaturated fatty acid, $24 \%$ monounsaturated fatty acid, and $13 \%$ saturated fatty acid. The main use of corn oil is in cooking, where its high smoke point makes it a useful frying oil. 